\title{
Evil and Agent-Causal Theism
}

\author{
Richard Brian Davis
}

In Explaining Evil: Four Views, edited by W. Paul Franks.

New York: Bloomsbury Academic, 2019, pp. 11-28

PLEASE DO NOT CITE THIS PRE-PUBLICATION COPY

That there is evil is evident all around us. Indeed, with the advent of the Internet and social media, we're no doubt more aware (painfully so) of the depth and scope of evil than at any other time in human history. However, while evil is confirmed by the facts of experience, it is not always easy to find room for it in our thinking. There is, for example, the claim that evil fits rather badly with theistic ways of thinking-that to believe There is a God is contradictory to (or at least strongly disconfirmed by) the belief that there is evil. Substantial philosophical time and resources have been spent on exploring this alleged incongruity. And philosophy, to my mind, is much the better for it. Surprisingly little attention, however, has been paid to the question of whether there might be other systems of belief where evil is a bad fit.

In this chapter, I attempt to show that evil exists only if what I call Agent Causal Theism (ACT) is true. According to ACT, human beings are immaterial, conscious agents endued (by God) with a power of self-motion: the power to think, decide, and act for ends in light of reasons, but without being externally caused to do so (even by God himself). By contrast, I argue that there is no space for evil in the worldviews of naturalistic Darwinism or theistic Calvinism.

\section{Making Sense of EviL}

Evil is not hard to recognize. If it were, the so-called problem of evil for theism wouldn't have nearly the psychological force it does. Strangely, however, you can look high and low in that literature, and you will scarce find any account of evil: what it is essentially or how it arose. ${ }^{1}$ I recently asked a famous philosopher known for his work on the problem of evil, whether in his many travels anyone had ever defined evil to his satisfaction. Without a moment's hesitation, he replied "No." I then asked what he thought it was. This time there was a pause: "It's enough to say it's 'bad stuff."

But is that enough? Here we don't need an analytic definition of evil in terms of necessary and sufficient conditions; that would be extremely ambitious given the complex and wide-ranging nature of evil. It will suffice to have a rough-and-ready, working definition: something that gives us a basic grasp (however frail) of the concept, setting the stage for assessing attempts to account for it. To get our bearings, suppose we turn to standard discussions of the problem of evil. Here we meet with the

\footnotetext{
${ }^{1}$ A notable exception is Mark T. Nelson, "Naturalistic Ethics and the Argument from Evil," Faith and Philosophy 8 (1991): 368-379.
} 
distinction between moral and natural evil. Moral evil is the evil we normally associate with human choices-e.g., to drive a truck into a crowd of innocent people, or to use chemical weapons on one's foes and enemies. Much of the terrible pain human beings (and other sentient animals) have suffered has resulted in this way-at the hands of human beings. But not of course all of it. For the religious sceptic is sure to remind us here of natural evils: "a volcano unexpectedly erupts and spills burning lava onto a village; or a tidal wave inundates a coastal town." ${ }^{2}$ These are evils the cause of which is purely natural (e.g., plate tectonic movement) and not the result of human (or nonhuman) choice.

Taking the volcano example as a paradigm case gives us something like a sensation-based account of evil. According to Epicurus, "all good and evil lies in sensation." 3 A volcanic eruption in itself is neither good nor evil; it is simply an event that happens. It is only when it leads to pain and suffering on the part of the villagers (or sentient non-human animals) that we're at all inclined to call the eruption a natural evil. On the other hand, restricting our attention to cases of human wickedness suggests a subject-based account of evil. The most familiar cases of evil, of course, involve human decisions (e.g., Truman's to drop the atomic bombs) and actions (e.g., the Boston Marathon bombing). And while these evils are often associated with painful sensations, they aren't constituted by them. This is evident from the fact that there are evils that lack (or could lack) this association. For example, there are thoughts, intentions, and desires that may never be acted upon, may never terminate in painful sensations, but are nevertheless evil-and intrinsically so. ${ }^{4}$ But if so, evil cannot lie in sensation. Instead, it is plausibly thought to be bound up with a "failure to perform some duty" or "to exhibit some crucial virtue."5

Now let's say this is right or at least nearly so. The question arises: is evil, then, simply wrongdoing? According to Calder, there is a crucial difference. ${ }^{6}$ Evil isn't just a matter of going very wrong, or piling up moral wrongs until some threshold for evil is reached. Paradigm cases of evil point to an inexcusable intent to bring about or permit significant harm when it is within one's power to have done otherwise. If a significant harm is one that "a normal rational human being would take considerable pains to avoid,"7 Epicurus' painful sensations are certainly in view even if they don't define evil. What evil involves-essentially and at its core-is an immoral thought, desire, decision, or action (freely) entertained or undertaken by a conscious, rational agent to deliberately cause or permit significant harm to be done to herself or others for the sake of an unjustifiable end.

\footnotetext{
2 James Rachels, Created from Animals: The Moral Implications of Darwinism (Oxford University Press, 1991), p. 105.

3 Epicurus, A Guide to Happiness (Phoenix Books, 1996), p. 2.

4 To underscore this point, a proponent of ACT might appeal not only to her own introspective experience, but also prior tradition: "For out of the heart come evil thoughts, murder, adultery, sexual immorality, theft, false witness, slander" (Matthew 15:19).

5 Nelson, "Naturalistic Ethics and the Argument from Evil," p. 370.

${ }^{6}$ See Todd Calder, "Is Evil Just Very Wrong?” Philosophical Studies 163 (2013): 177-196.

7 Ibid., p. 188.
} 
This partial sketch captures the notion I have in mind, and while there is need for more chisholming (when isn't there?), it will be adequate for present purposes. The thing to see is that if this is even approximately what evil comes to, the only worldviews capable of accommodating the reality of evil will be those that can make room for conscious agents with the power to think, desire, decide, and act freely. In what follows, and solely for the sake of convenience, I shall carry out my discussion of ACT and its rivals primarily in terms of our decisions and actions with the proviso that thoughts, desires, and intents are equally in view.

\section{MAKING SPACE FOR EVIL}

\subsection{THE FREEDOM CONDITION}

Thus, a staff moves a stone, and is moved by a hand, which is moved by a man.

\section{- Aristotle}

To do something evil is to do something for which one is guilty, responsible, and perhaps even subject to punishment. In an ordinary and straightforward sense, this implies that evil is freely chosen. According to ACT, to say that I have freely performed an action means, in the first place, that I myself have decided to undertake it. I am the agent or author of that action: its first mover, so to speak. Thus, it is my responsibility. Evil results from my misuse of the power I have of self-motion, of initiating volitions to act-e.g., making decisions or forming "effective intentions" have for acting.

Now why think I have this sort of freedom-call it agent-causal freedom? Two reasons. In the first place, it fits in perfectly with the facts of my experience. At least on some occasions (the ones on which I take myself to have acted freely), I experience myself as having decided to act upon one set of reasons when I am perfectly aware that I could have acted upon another. As Hasker notes, this may not prove that I have agentcausal freedom, but "it does establish a powerful presumption in its favor-a presumption that ought to be overcome only by the strongest possible reasons for the contrary position." 9 The meagre possibility that I am wrong hardly counts as the strongest possible reason for thinking I am.

Furthermore, if I do not have the power of self-motion, then my decisions to act (/refrain from acting) have been determined by a series of prior causes, in which case I am not, strictly speaking, an agent-i.e., the originating cause of my decisions. Rather, I am a mere patient acted upon by necessitating causes. To speak of "my decision" to do evil in that case is just a façon de parler: a mere name we give to an effect produced in me by its real author (something or someone else up the causal chain). In actual fact, the "decision" isn't mine. It doesn't originate with me; it happens to me. However, as

\footnotetext{
${ }^{8}$ This is Hasker's term of art, referring to "a state of mind which, in the normal course of events, flows naturally into the intended action; no further deliberation is required." See William Hasker, The Emergent Self (Cornell University Press, 1999), pp. 88.

${ }^{9}$ Ibid., p. 85.
} 
Samuel Clarke, the Great Libertarian, points out, this immediately leads to grief. For it means that I am no more a responsible agent than is a watch or a clock:

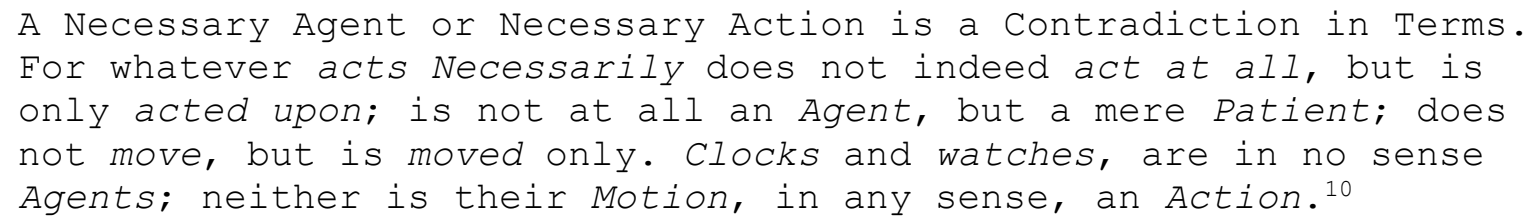

Thus, no man "can be angry with his clock for going wrong." ${ }^{11}$ And even supposing that a clock were endued (by God) with intelligence and perception, all that would imply is that it had "understanding enough to feel and be sensible that its weights necessitated"12 the movement of its hands. It wouldn't indicate that the clock could in any sense be held responsible for those movements.

This raises a related point. The reason we don't blame clocks for their evil doing is that we recognize that they cannot avoid doing what they do. Given the arrangement of their parts, and the laws governing their mechanical interactions, they operate out of sheer necessity. They don't have the power of doing good or evil because they don't have the power to (decide to) do otherwise. Of course, if one of Clarke's sentient clocks (call it 'Lumière') could decide to speed up or slow down, Lumière might be praised for having kept the correct time (when it needn't have), and censured when it didn't (but could have), thereby misleading me about the time and making me late for an important meeting with the Dean. But if it isn't so much as possible that Lumière fail to operate as it does, then sentient or not, Lumière doesn't mark the time freely, and its movements aren't properly classed as good or evil.

But wouldn't the same go for human beings? If it turns out that there are always prior factors determining my actions and decisions, then wouldn't I, too, be incapable of good or evil? To be sure, human beings are vastly more complicated than clocks (even Apple Watches). But complexity isn't the issue here. As Derek Pereboom rightly notes, what's at stake is whether we human beings are genuinely free agents:

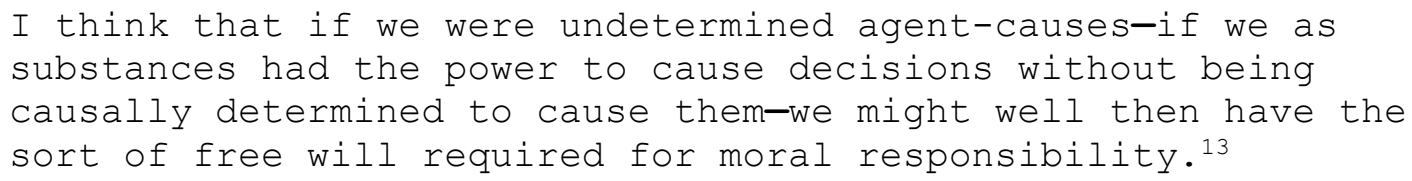

\footnotetext{
${ }^{10}$ Samuel Clarke, Remarks Upon a Book Entitled 'A Philosophical Enquiry Concerning Human Liberty'. Printed for James Knapton at the Crown in St. Paul's Church-Yard (London, 1717), p. 5. Compare Thomas Nagel: "There seems no room for agency in a world of neural impulses, chemical reactions, and bone and muscle movements. Even if we add sensation, perceptions, and feelings we don't get action, or doingthere is only what happens" (The View from Nowhere [Oxford University Press, 1986], p. 111).

${ }^{11}$ Samuel Clarke, "A Fourth Defense of an Argument," in The Correspondence of Samuel Clarke and Anthony Collins, 1707-1708, ed. Wm. L. Uzgalis (Broadview, 2011), p. 276.

${ }^{12}$ Ibid.

${ }^{13}$ Derek Pereboom, "Hard Incompatibilism," in Four Views on Free Will, John Martin Fischer, Robert Kane, Derek Pereboom, and Manuel Vargas (Blackwell Publishing, 2007), p. 94.
} 
And then we might also have the requisite freedom for doing good or evil. The question is: do we have agent-causal freedom? To begin with, we must note that there are certain worldviews that rule this out a priori, and therefore on which evil cannot be said to exist.

\subsection{Darwinian Determinism}

Consider, first, Darwinism-not the biological theory we all know and love, but its naturalistic construal. According to the most prominent and powerful versions of naturalism, there are no immaterial persons: no God or gods, no immaterial souls or selves (angelic or human). ${ }^{14}$ If there are any immaterial entities (numbers or sets, let's say), they are wholly abstract, impersonal, and causally effete-untouched by evolutionary forces. ${ }^{15}$ That's fair enough. According to Darwinian naturalism (DN), however, that's not the way things go for us. Human beings are entirely concrete and physical in nature. Thus Churchland:

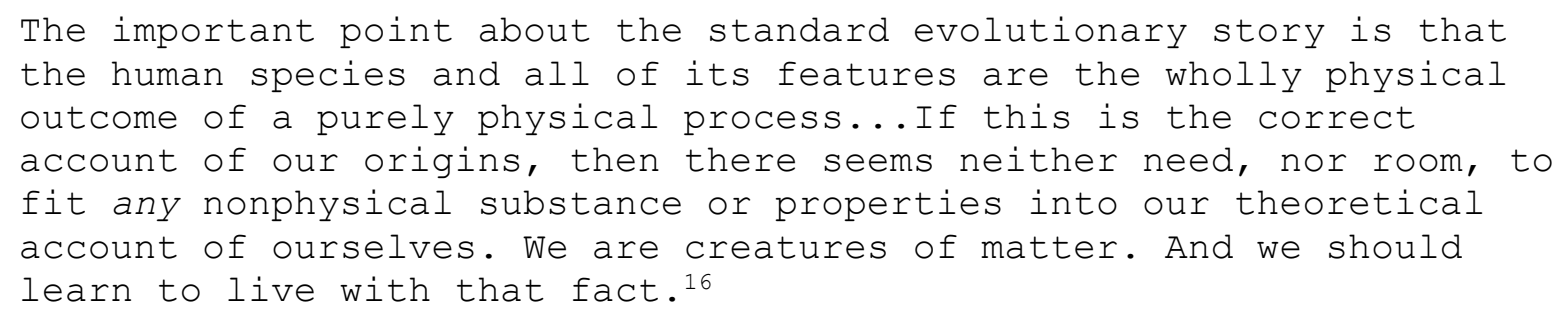

Perhaps this is (part of) what Pereboom is driving at when he says that agent causal freedom, while a "coherent possibility," is simply "not credible given our best physical theories." 17 If, according to DN, there is no "room" in the world for "any nonphysical substances or properties," then the physical realm-the only realm in which we have any foothold-is causally closed. It follows that everything true of us (e.g., our thinking, deciding, and acting) has been determined by a series of prior physical causes, stretching back to at least Haldane's "hot dilute soup," which, I assure you, could do none of these things. But then surely it wouldn't be within our power (yours or mine) to think, decide, or act anywise other than we do; in which case we wouldn't be responsible agents, but mere evolutionary Lumières: capable of neither good nor evil; subject to neither praise nor blame.

Now here the Darwinian naturalist is not without reply. According to Michael Ruse, for example, while we must admit that Darwinian mechanisms determine our

\footnotetext{
${ }^{14}$ There are some (very few) naturalists who subscribe to naturalism light: the view that although atheism is true, it doesn't follow that we aren't immaterial souls. Compare J.M.E. McTaggart: "Now there is a very common idea that an atheist must either be a materialist or a sceptic...But this, like many other common ideas, is erroneous" (Some Dogmas of Religion [London: Edward Arnold, 1906], p. 279). Surprisingly, McTaggart offers no argument at all for this startling assertion.

${ }^{15}$ According to Gottlob Frege, for example, if the truth of mathematical propositions is a product of evolution, then "it might even be that 2 × $2=4$ itself is destined...to develop into 2 × $2=3$ !" (The Foundations of Arithmetic: A Logico-Mathematical Enquiry into the Concept of Number, trans. J.L. Austin, $2^{\text {nd }}$ rev. ed [Northwestern University Press, 1980], pp. vi-vii).

${ }^{16}$ Paul Churchland, Matter and Consciousness: A Contemporary Introduction to the Philosophy of Mind (MIT Press, 2013), p. 35, emphasis added.

${ }^{17}$ Ibid.
} 
general features, we needn't think of this as robbing us of our specific ability "to change, to readjust and to go forward" in our struggle for survival:

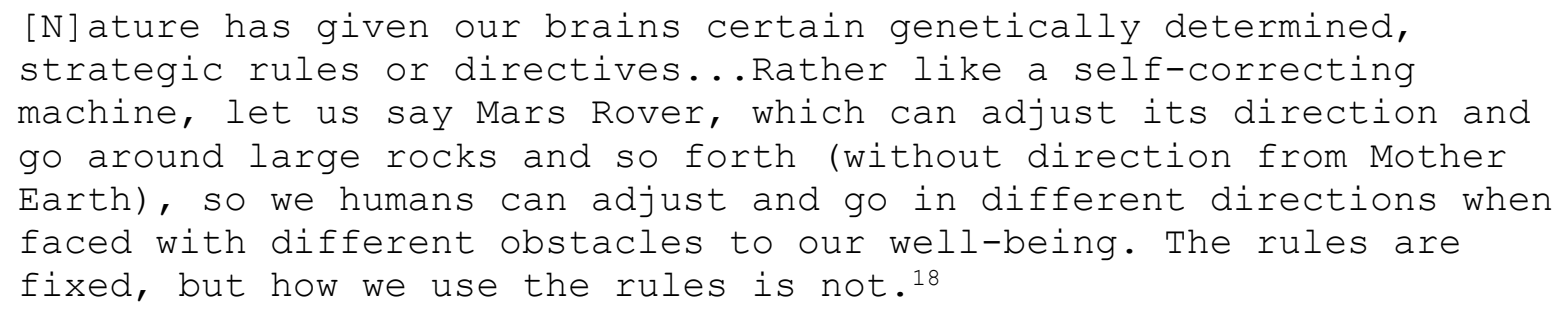

So the idea, I take it, is that just as the Mars rover can make autonomous course corrections ("without direction from Mother Earth"), we too can decide to adjust the course of our lives in "different directions," thereby establishing that we can do otherwise even within a Darwinian framework. We're causally determined to make course corrections, but not to take this or that course. That is up to us. We make the mid-course adjustments.

Now Ruse's argument is an analogy: a likening of self-determining (human) agents to self-driving machines. This naturally raises the question: just how similar are these things in the relevant respects? Simply noting the fact that the Mars Rover can "adjust its direction" doesn't even begin to show that (like us) it can be held responsible for its actions or decisions. And it's not difficult to see why.

A self-driving vehicle, like the Rover, operates by way of a complex system of cameras and sensors. These function to detect the movement and position of nearby objects, and then transmit that data to an onboard computer hardwired up front with fixed "rules"-for example:

CLIFF AHEAD: If there is a cliff ahead, apply maximum pressure to the brakes.

Now let's dub the computer (likely some Apple product or another) 'iOS'. It is important to see that iOS doesn't decide whether or even how a rule like CLIFF AHEAD is used. Whether it is used on a given occasion depends on its antecedent being satisfied: a condition that will be met only if there is a cliff ahead or not. But surely that isn't the sort of thing that is decided by the Rover's iOS-not unless it happens to be outfitted with Kant's 12 Categories of the Understanding! How it is used is settled solely by its consequent. Upon receiving "cliff ahead" data, iOS has no choice about whether to brake. It therefore lacks the freedom we ordinarily associate with being responsible for what one does. The fact is: iOS is little more than Lumière without the sentience. The application to the human iOs (i.e., our brains) is patent.

There is a further difficulty. If our brains operate in similar fashion, we cannot censure the degenerate thinking that so often motivates evil activities. Consider a simple example. ${ }^{19}$ Just prior to Vladimir Putin's signing into law a new measure decriminalizing

\footnotetext{
${ }^{18}$ Michael Ruse, "Naturalist Moral Nonrealism," in God and Morality: Four Views, ed. R. Keith Loftin (IVP Academic, 2012), p. 60.

${ }_{19}$ For details, see Tom Embury-Dennis, (2017, February 9). The Independent. Retrieved from http://www.independent.co.uk/news/world/europe/russian-newspaper-proud-bruises-vladimir-putindomestic-abuse-violence-signs-controversial-law-a7570351.html.
} 
some forms of domestic violence (including wife-beating), the Russian paper Komsomolskaya Pravda ran a piece defending the move. Appealing to the findings of evolutionary psychologist Satoshi Kanazawa, the author of the article reasoned as follows:

p: $\quad$ Women subjected to non-lethal domestic abuse have an increased likelihood of giving birth to boys.

Therefore,

$q$ : We need to pass a law decriminalizing non-lethal domestic abuse.

Now let's suppose that this represents the actual line of thinking Putin relied upon in coming to his decision-a decision we all recognize as plainly and appallingly evil. ${ }^{20}$ It is natural to think that Putin was responsible not only for the decision, but also the thinking that fueled it.

But is that something Ruse can affirm? I doubt it. Let 'T(p)' and 'T(q)' stand for Putin's thought that $p,{ }^{21}$ and Putin's thought that $q$, respectively. Then consider the transition from $\mathrm{T}(p)$ to $\mathrm{T}(q)$. What explains that? The obvious initial reply is:

ANSWER: $\quad \mathrm{T}(q)$ obtains because $\mathrm{T}(p)$ obtains.

However, there is a subtle ambiguity in the word 'because' here. ${ }^{22}$ Does it indicate the relation of Cause-Effect (e.g., "Blood circulates because the heart pumps") or GroundConsequent (e.g., "Isaac thinks that gravity has a cause because he thinks it is a force")? ${ }^{23}$ Construed in the first way, what ANSWER tells us is that

ANSWER $_{1}: \quad \mathrm{T}(q)$ has been caused by $\mathrm{T}(p)$.

But ANSWER can also be taken to express a movement in our thinking from a rational ground to a consequent. That gives us a vastly different reading:

ANSWER $_{2}: \quad \mathrm{T}(q)$ has been inferred from $\mathrm{T}(p)$.

Now the thing to see is that these two answers run at cross-purposes. Intuitively,

\footnotetext{
${ }^{20}$ It was sure to increase violence against women. Moreover, the justification for (knowingly) allowing these significant harms was inexcusable: the mere desire for more male babies.

${ }^{21}$ Following Wielenberg, I take the locution 'S's thought that $p$ ' to include S's “conscious endorsement" of p. See Eric J. Wielenberg, God and the Reach of Reason: C.S. Lewis, David Hume, and Bertrand Russell (Cambridge University Press, 2008), p. 95.

${ }^{22}$ Noted by C.S. Lewis in his chapter "The Cardinal Difficulty of Naturalism," in Miracles (Fontana Books, 1960), p. 19. For helpful reflections on Lewis here, see Wielenberg, God and the Reach of Reason, pp. 9496. See also Victor Reppert, "The Argument from Reason," in The Blackwell Companion to Natural Theology, eds. William Lane Craig and J.P. Moreland (Blackwell Publishing, 2009), pp. 356-358.

${ }^{23}$ Just to be clear: what is in view here is an inferential movement in thinking. We are not talking about the static (platonic) relation of logical entailment that necessarily obtains between the premises and conclusion of valid arguments.
} 
ANSWER $_{2}$ will be an inference for which Putin can be praised or blamed only if he could have refrained from $\mathrm{T}(q)$ given $\mathrm{T}(p)$. The failure here isn't simply logical or epistemic; given the stakes, it is also a moral failing. But on DN, I take it, ANSWER $\mathrm{B}_{1}$ is axiomatic: $\mathrm{T}(p)$ and T $(q)$ are physical event-structures in Putin's brain; and then if Ruse is right, these are related as Cause and Effect by "genetically determined, strategic rules or directives." ${ }^{24}$ Not only is $\mathrm{T}(q)$ caused by $\mathrm{T}(p), \mathrm{T}(p)$ is itself the final link in a chain of prior Darwinian causes. It's determinism all the way down.

Someone might object that Putin certainly is responsible for his musings on domestic abuse. For we can easily imagine him refraining from $\mathrm{T}(q)$ under a different set of circumstances, perhaps even embracing T(not- $q$ ). But here there is confusion. The question isn't whether Putin could have failed to think $q$, if instead of thinking $p$ he had been caused to think some other proposition. That is possible but presently irrelevant. It only means that Putin's “refraining" isn't free, and thus not something for which we're inclined to give him credit. The salient question lies in a different direction: can Putin refrain from (thinking $q$ while being caused (by thinking $p$ ) to think $q$ )? And the answer, on DN, seems perfectly clear: he cannot.

The problem here, fundamentally, is that DN fails to respect the basic distinction between drawing a conclusion (for which one can be appraised) and being determined to hold it (for which one cannot). These are decidedly not the same. Indeed, as we all know, the right use of our reason in distinguishing good from evil (and acting accordingly) requires that we routinely exercise our power to resist certain inferences. ${ }^{25}$ Unfortunately, if the universe is causally closed, and if our thoughts just are physical event-causes, this is a power we do not possess.

\subsection{Divine Determinism}

At this juncture, it is tempting to think that moving to an open universe (say, a theistic one) might greatly improve our chances of securing the freedom necessary to account for evil's coming to be. The temptation must be resisted-at least in certain respects. For there are varieties of theism every bit as deterministic (and hence evil-negating) as the Darwinian worlds of Ruse, Sagan, and Dawkins. I'm thinking, of course, of Calvinistic theism, according to which everything that occurs in human history down to the smallest detail (including all the evil there is) is ordained by God.

Now it seems to me that as far as freedom and moral responsibility are

\footnotetext{
24 The point I am making here is not the one frequently imputed to C.S. Lewis, namely, that one thought cannot simultaneously both cause and entail another. This point has been challenged by Lewis' critics. See, for example, Wielenberg, God and the Reach of Reason, p. 95; and Peter van Inwagen, "C.S. Lewis' Argument Against Naturalism," Res Philosophica 90 (2013): 113-124. It seems to me, however, that Lewis' point holds if (following DN) we take thoughts to be physical event-structures in the brain. On this point, see Paul M. Gould and Richard Brian Davis, "Modified Theistic Activism," in Beyond the Control of God: Six Views on the Problem of God and Abstract Objects (Bloomsbury Academic, 2014), pp. 52-53. ${ }^{25}$ See Isaac Watts, Logic: The Right Use of Reason in the Inquiry After Truth (Soli Deo Gloria Publications, 1996) for a discussion of the various temptations to rash judgment that must be resisted. These include (but are not limited to) prejudice, overindulged passions and appetites, and the fear of cultural disapproval.
} 
concerned, Calvinism is no less unlovely than naturalistic Darwinism. Thus, for example, Calvin declares of God: "His will is, and rightly ought to be, the cause of all things that are...it pertains to his might to rule and control everything by his hand."26 How is it that everything occurs according to the set purpose and foreknowledge of God? Calvin's answer, apparently, is that God causes everything: every human thought, desire, decision, and action. He knows and is in control of these things because (directly or indirectly) he is the cause of them.

There are obvious problems here. If God's will is "the cause of all things that are," then undoubtedly God is the author of evil-a welcome conclusion no doubt to atheist arguers from evil who have always suspected as much. For if we know anything at all, we know that evil exists. The reply, of course, will be that God doesn't cause these things; he merely permits them. There is a difference. Thus, according to the Calvinist philosopher Paul Helm,

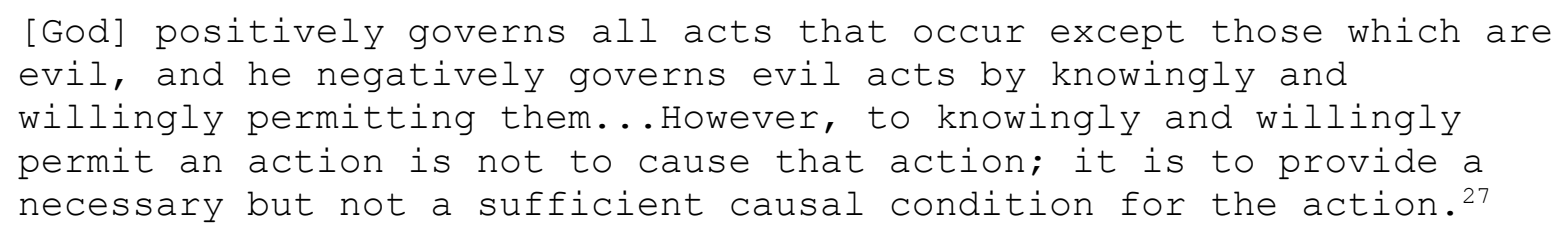

Since God only permits the evil act, he isn't culpable for it. The culpability remains with the human agent who is its cause. In principle, I suppose, this is the right thing for the Calvinist to say. Unfortunately, it plays havoc with her system.

Following Helm, let's suppose that God doesn't causally determine everything. The question, in that case, is how God could know and ensure that things unfold according to plan. How is that supposed to work? Helm has a suggestion:

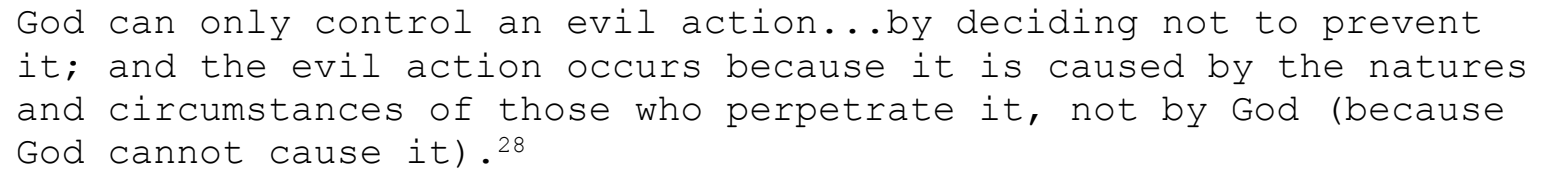

Or again, he says, "[h]uman nature being what it is, evil results." 29 We "have an inclination to evil."3o Well, perhaps so; but even if so, that hardly explains how God could know in advance that (say) Judas will betray Christ for exactly thirty pieces of silver, as opposed to forty, fifty, or a hundred. How is that specific detail supposed to be deduced from the general fact that Judas has evil inclinations? Wouldn't that be like trying to figure out what I'll be ordering at dinner tonight from the general fact that I'm hungry? It seems a hopeless business.

\footnotetext{
${ }^{26}$ Calvin, Institutes of the Christian Religion, Volume 1, ed. John T. McNeill (Westminster John Knox Press, 1960), pp. 949, 956, emphasis added.

${ }_{27}$ Paul Helm, "The Augustinian-Calvinist View," in Divine Foreknowledge: Four Views, eds. James K. Beilby and Paul R. Eddy (InterVarsity Press, 2001), pp. 179-180.

${ }^{28}$ Helm, "The Augustinian-Calvinist View," p. 179.

${ }^{29}$ Ibid., p. 177.

${ }^{30}$ Ibid.
} 
In any event, the fact remains that all evil actions are caused: if not by God, then by our natures and circumstances. I doubt Ruse would say much different. Not surprisingly, to secure our responsibility for evil, Helm goes on to prescribe a strong dose of soft determinism or compatibilism: "the idea that human actions are free in a sense that is consistent with determinism," 31 and thus "compatible with human moral responsibility." 32 For although Judas' could not have done otherwise under the circumstances, nevertheless he doesn't act contrary to his desires. Judas is therefore both free and responsible.

This is a familiar move, but its attractiveness rather abates once we learn that (on both Calvinism and Darwinism) the evil desire Judas is determined to act upon is one he was determined to have. Hence, if being free means doing what one wants or desires, Judas is free only in the sense that Lumière is. He is subject to his predetermined thoughts and desires in the same way that Lumière is subject to the operation of its weights. He doesn't direct them; they direct him. We can call this freedom if we like, but giving it that name won't make Judas responsible for his actions. Indeed, if this is what freedom is, I think we have a good reason for drawing precisely the opposite conclusion: Judas is guilty of neither wrongdoing nor evil.

But let us waive these points, assuming for argument's sake that compatibilism is true. How does that help? Compatibilism can only play its role if there is evil. But that is a rather big if, I think, for the likes of Helm and Ruse. Here each faces a daunting origins problem. For Helm's part, he recognizes there is "the unresolved problem of the entry of evil into a universe created good...and exactly how evil comes about in a world created by an all-good God."33 For Calvinism, however, the problem isn't only unresolved; it is unresolvable. This is because of its twin commitments to:

C1: $\quad$ Evil is the effect of an evil-inclining human nature

and

C2: $\quad$ Evil-inclining human natures are an effect of "the Fall."34

The expression "the Fall" refers to a free and deliberate choice to disobey God made by those human beings originally created by God. (Call this choice DISOBEY.) We can think of DISOBEY as the "original sin" or first evil so to speak.

Now $\mathrm{C} 1$ and $\mathrm{C} 2$ are incompatible: if either is true, the other is not. Let 'EN' stand for the first evil-inclining nature. According to C1, DISOBEY is caused by EN. According to $\mathrm{C} 2$, DISOBEY causes EN. So we have a cart (and after) before the horse problem. Moreover, cleaving to $\mathrm{C} 1$ leads to a fatal dilemma. Note first that if EN causes DISOBEY, but God is the cause of EN (in virtue his creating human beings), then God is the cause of DISOBEY, 35 and thus the originating cause of evil.

Understandably, Helm rejects this alternative. What then is the cause of DISOBEY? If it isn't the human agent exercising her power of self-motion (i.e., to decide

\footnotetext{
${ }^{31}$ Ibid., p. 169.

${ }^{2}$ Paul Helm, "God, Compatibilism, and the Authorship of Sin," Religious Studies 46 (2010): 116.

33 Helm, "The Augustinian-Calvinist View," pp. 178-179.

34 See Helm, "The Augustinian-Calvinist View," p. 177.

35 This follows by the transitivity of causation: A causes B; B causes C; therefore, A causes C.
} 
to act, but without being caused to do so), then the efficient cause of DISOBEY must either be the agent's nature, circumstances, or reasons for acting. But it can't be her nature ${ }^{36}$ or circumstances, since (by hypothesis) everything was "created good." Nor can it be her arguments, reasons, or motives for acting; for these are abstract notions at best. They aren't (and cannot be) efficient causes of action.

It follows that it is the agent herself who brings about DisOBEY. She decides to DISOBEY in light of the reasons she possesses. But those reasons don't cause DisOBEY; they merely occasion and inform it. The upshot for Helm is this: if $\mathrm{C}_{1}$ is true, then either God is the agent-cause of evil or human beings are. Since Helm agrees that God isn't, he is committed to saying human agents are. In a strange twist, then, the first and paradigm case of a free choice to do evil supports Agent Causal Theism (over Helm's Calvinism). For consistency's sake, therefore, I heartily recommend it to him.

Ruse is another matter. He faces a different (thankfully shorter) dilemma. On the sensation or subject-based accounts of evil, there cannot be evil unless there are conscious agents. But on Darwinian naturalism, whence come these agents with the power to think, decide, and act? Helm at least can appeal to a Supreme immaterial, conscious agent (God) as the cause of these powers. What can Ruse appeal to?

\subsection{THE CONSCIOUSNESS CONDITION}

Intelligence is not figure and consciousness is not motion.

\section{-Samuel Clarke}

Suppose the universe originally consisted of nothing but matter in motion. Could a being such as myself, a being endowed with consciousness, have ever arisen from such a Democritean state of affairs? What I propose to argue briefly is that it couldn't. ${ }^{37}$ I'll conduct the argument in terms of my own consciousness, which I'll name ' $\mathrm{C}$ '. (You shall have to make the application to yourself.) Now $\mathrm{C}$ is not the property being conscious; it is a trope, as philosophers like to say: my concrete instantiation of being conscious. Following Clarke, think of $\mathrm{C}$ as the introspective act "by which I know that I think, and that my thought and actions are my own and not another's." 38 As far as experience goes, $\mathrm{C}$ presents itself to me as single (it is one consciousness) and unified (it has no parts).

And now let's suppose, following DN, that I am identical with my brain ('B' for short), consisting of parts $\mathrm{p}_{1}, \mathrm{p}_{2}, \ldots \mathrm{p}_{\mathrm{n}}$. Like any material system, $\mathrm{B}$ just is the sum of its parts; it isn't one more thing beyond that collection of parts. Hasker puts it nicely:

The brain as a whole is not an additional concrete object over and

above its parts, any more than, in Gilbert Ryle's example, oxford

${ }^{36}$ Or anything following from her nature-e.g., impulses or desires to act.

37 The argument I present here is by no means original. It traces back to Leibniz (a single paragraph in his Monadology §17) and also Kant (a slighter longer paragraph in the Second Antinomy). It was also defended at length and in great detail by Samuel Clarke. See The Correspondence of Samuel Clarke and Anthony Collins, 1707-1708, ed. Wm. L. Uzgalis (Broadview, 2011). For a recent semi-technical formulation, see Hasker, The Emergent Self, pp. 122-146.

${ }^{38}$ Samuel Clarke, "A Second Defense of an Argument," in The Correspondence of Samuel Clarke and Anthony Collins, p. 90. In a looser sense, 'consciousness' also refers to "the direct act of thinking, or the power or capacity of thinking...or the power of self-motion or beginning motion by the will” (ibid., p. 108). 
University is an additional object over and above the colleges, libraries, and so on of which it consists. ${ }^{39}$

But then for $\mathrm{C}$ to inhere in (/belong to) $\mathrm{B}$ is just for it to inhere in $\left\langle\mathrm{p}_{1}, \mathrm{p}_{2}, \ldots \mathrm{p}_{\mathrm{n}}\right\rangle$. But surely this is absurd. For it implies either that

(1) Each part of $<\mathrm{p}_{1}, \mathrm{p}_{2}, \ldots \mathrm{p}_{\mathrm{n}}>$ has $\mathrm{C}$-that is, $\mathrm{p}_{1}$ has $\mathrm{C}, \mathrm{p}_{2}$ has $\mathrm{C}, \ldots \mathrm{p}_{\mathrm{n}}$ has $\mathrm{C}$;

or

(2) Each part of $<\mathrm{p}_{1}, \mathrm{p}_{2}, \ldots \mathrm{p}_{\mathrm{n}}>$ has a part of $\mathrm{C}$, with $\mathrm{C}$ consisting in the aggregate of these partial consciousnesses. $4^{4}$

Here (1) and (2) are beset by similar problems. First of all, there is a panpsychism problem; they are both committed to the wholly incredible thesis that each and every part of my brain (however minute) is conscious! Secondly, there is a composition problem. My consciousness, $\mathrm{C}$, is single and undivided; however, an aggregate of distinct consciousnesses is not. ${ }^{4}$ When you compound distinct parts you get a complex (not a unified) whole. It won't help to say that these multiple consciousnesses are unified "if there is something it is like for a subject to be in [these] states simultaneously." 42 For here there is no single subject that has (and thus unifies) this multitude. Our subject is B, a material aggregate composed of a dizzying number of definite and discrete parts. And, I'm sorry to say, it is a composition fallacy to argue that since each of these parts is conscious or quasi-conscious, there is something it is like for $\mathrm{B}$ (that compound whole) to be conscious.

But all of this is too easy, you say. No Darwinian materialist thinks the parts of the brain are conscious or partially conscious. Of course not. Rather, the thinking is this: the properties of, and relations between B's parts, taken together, somehow generate consciousness at the level of the material whole (B itself). Let ' $R\left[\mathrm{p}_{1}, \mathrm{p}_{2}, \ldots \mathrm{p}_{n}\right]$ ' stand for the relational complex. The claim, then, is that $R\left[p_{1}, p_{2}, \ldots p_{n}\right]$ causes $C$ to inhere in $B$ even though the parts of my brain are utterly void of consciousness. Is that a plausible suggestion? Well, I don't think so.

The problem is essentially categorial. Samuel Clarke, the Great Newtonian, puts it this way. Take all the powers and properties of a material system that you please, and then unite them "in one operation or power to operate." 43 This may well result in the material compound's having a different power or property than those found "in the particles singly considered" (as, for example, when "two triangles put together make a

\footnotetext{
39 Hasker, The Emergent Self, p. 139.

40 "Partial consciousnesses": in terms of their scope, not their degree of consciousness.

${ }^{41}$ Objection: "You say that the consciousness of the parts is distinct from C. But on (1) that isn't true. Each part of B has C.” Reply: consider the property being my consciousness or being C. Each instancing of being $C$ by the separate and distinct parts of $B$ will count as a separate and distinct trope. This is yet another reason for thinking B's parts cannot have C. For if they could, then C (that single trope) could be identical with a host of numerically distinct consciousness tropes, namely, those of $p_{1}, p_{2}, \ldots p_{n}$. ${ }^{42}$ See Tim Bayne and David Chalmers, "What is the Unity of Consciousness?" in The Unity of Consciousness: Binding, Integration, Dissociation, ed. A. Cleeremans (Oxford University Press, 2003), p. 32.

${ }^{43}$ Clarke, "A Second Defense of an Argument," p. 94.
} 
square"44). But it will always be of the same species-say, another geometrical figure. Yet he says,

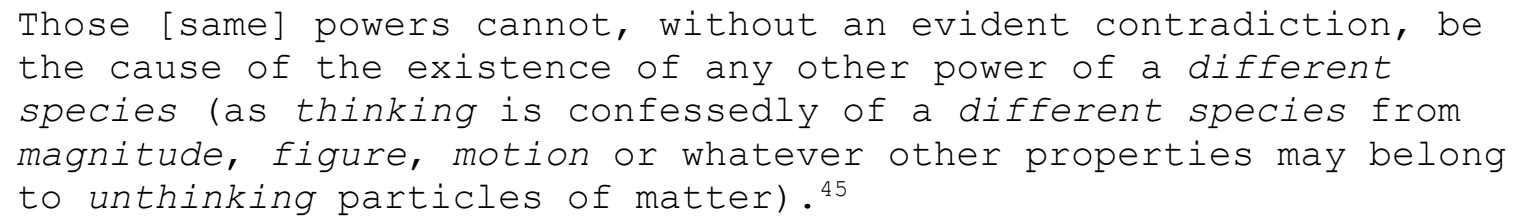

We are given the effect by hypothesis. My brain is conscious. But if that is the effect, what is its cause? Since the brain is nothing but the sum of its parts, to get consciousness at the compound level, it must be 'built up' out of those parts (and their properties). But therein lies the problem. For thinking and consciousness are "the farthest distant from the known properties of matter." 46 They are radically categorially distinct. You might as well argue that we could get a flavor or a color by adding 7 and 5 . So we have an effect (that which is caused) but no properly outfitted cause to produce that effect. This isn't just “magic" (as Nagel suggests47); it's getting something from nothing-a plain contradiction. 48

The upshot is that my thinking or consciousness cannot reside in my brain, or for that matter any material object composed of parts. Darwinian mechanisms, as wonderfully creative as they are at the biological level, can never generate consciousness or thinking of the sort that would make evil even a possibility. The conclusion to be drawn (since I am conscious) is that my consciousness resides in an undivided, immaterial substance. However, with naturalism out of the picture, we're left with only two possible explanations of this fact. My consciousness has either been communicated to me via an endless series of conscious dependent beings (an ESCDB), not terminating in Haldane's unconscious soup; or it has been produced in me by an immaterial, conscious Supreme Agent (i.e., God). But the former collapses into the latter here, since the cause or reason of an ESCDB must lie outside that series. For, by definition, no member of an ESCDB-hence the series itself-exists by a necessity of its own nature. The cause of my consciousness (and, by extension, my powers of thinking and agency) is therefore to be found in the divine will.

\section{CONCLUSION}

That there is evil is undeniable. The question is how to account for it. And the fact is: not all worldviews can. If evil resides in sensation, as Epicurus tells us, then to account for evil requires that we account for consciousness-something without which there couldn't be pain or suffering. If we opt for a subject-based account of evil, things only get more difficult. For then we have the additional chore of explaining how there could

\footnotetext{
${ }^{44}$ See Samuel Clarke, A Demonstration of the Being and Attributes of God, ed. Ezio Vailati (Cambridge University Press, 1998), p. 42.

45 Clarke, "A Second Defense of an Argument," p. 94.

${ }^{46}$ Clarke, Demonstration, p. 57.

47 Thomas Nagel, Mind and Cosmos, p. 56.

${ }^{48}$ This same basic difficulty plagues Hasker's valiant attempt to generate an emergent (immaterial) self or substance (i.e., a "soul-field" as he calls it) from $\left.\mathrm{R}<\mathrm{p}_{1}, \mathrm{p}_{2}, \ldots \mathrm{p}_{\mathrm{n}}\right\rangle$, and then to attribute my consciousness to my soul-field rather than my brain. See Hasker, The Emergent Self, pp. 188-203.
} 
be evil if conscious agents lack the power to author (/originate) their actions or decisions for the sake of ends and in light of reasons. Darwinian naturalism and Calvinistic theism rob us of this power. Hence, they evacuate the world of evil, or perhaps (as on Calvinism) locate its origins in God.

By contrast, Agent Causal Theism faces none of these obstacles. It provides an intuitive, principled basis for claiming that evil and the responsibility for it reside in the power of conscious human agents to freely originate thoughts, decisions, and actions which might well (if that power is misused) bring about evil. But neither you nor I would have this power in the first place, if there weren't an immaterial, conscious Supreme Agent. Ironically, then, evil can only exist if God does. So he does. 49

${ }^{49}$ Special thanks Paul M. Gould and R. Keith Loftin for helpful comments and unflagging encouragement. 